\title{
ST. RENE: THE PATRON SAINT OF ANAESTHETISTS AND A PATRON SAINT OF CANADA
}

\author{
Rod K. Calverley
}

\begin{abstract}
René Goupil, the Patron Saint of Anaesthetists, and a Patron Saint of Canada, was born in Angers, France in 1608 and studied surgery. He joined the Jesuits as a donne or volunteer worker in 1640 and served in the then tiny colony of Quebec as one of the first medical workers of Canada. After earning meritorious praise for his skills, he again volunteered to attend the Hurons at Sainte Marie, a mission far beyond the frontiers. René's canoe party was ambushed. He was captured by the Mohawks and endured eight weeks of cruel torture before being killed on September 29, 1642. René was the first of eight North American martyrs whose dedication was recognized by canonization in 1930. St. René was appointed Patron Saint of Anaesthetists in 1951 .
\end{abstract}

A FEW SURGEONS AND APOTHECARIES accompanied Champlain and other 17 th-century French explorers of North America.' Each of these people and the colonists who followed them experienced hardships and dangers in a strange and hostile land, but the trials of one relatively unknown man stand apart. In 1640 René Goupil, a donné or lay associate of the Jesuits, became the first medical missionary in Canada. ${ }^{2}$ After two years of compassionate service in Quebec in the mission of St. Joseph de Sillery, he volunteered to travel deep into the wilderness to serve at Sainte Marie near Lake Huron. During that canoe journey he and his companions were captured by raiding Mohawks. After cruel and repeated torture he was murdered on September 29, 1642, the first of eight Jesuit martyrs.3.4 They were canonized in 1930 and named Patron Saints of Canada on October 16, 1940. While René Goupil's death antedated the discovery of anaesthesia by two centuries, the record of his personal and professional qualities led to his selection as the Patron Saint of Anaesthetists in 1951.

\section{Biography and Canonization}

René Goupil was born in Angers, France, in May 1608 at the time of Champlain's founding of the Quebec colony. Goupil studied medicine and

Rod K. Calverley, M.D., F.R.C.P.(C), Associate Clinical Professor, Department of Anaesthesiology, University of California, San Diego.

Address reprint requests to: Rod K. Calverley, M.D., Department of Anaesthesia, VA Medical Center, 3360 La Jolla Village Drive, San Diego, California 92161 , U.S.A.

Canad. Anaesth. Soc. J., vol. 27, no. 1, January 1980 surgery as a young man. The details of those studies are unknown, but it is apparent from notes left by the Jesuits that while in Quebec he was considered a well-educated and competent practitioner and not an unskilled barbersurgeon ${ }^{5}$.

He became a novice at a Jesuit House in Paris during March 1639, but was released from his novitiate after several months owing to ill health. One record attributes his release to deafness: "Renatus Goupil a tirocinio Parisiensi exclusus erat quia surdaster." gests a congenital deafness, he appears to have recovered, for his handicap is not mentioned again.

During his time as a novice, René would have heard of the exploits of the first Jesuit missionaries of New France. Cardinal Richelieu and the Court of Louis XIII had fostered the North American Jesuit mission. The Jesuits served the colonists of Quebec and also penetrated the wilderness far beyond any military or economic support to evangelize among the native peoples.

As the mission field expanded, the Jesuits recruited a few lay supporters. The donnés (given men) donated their services for life and brought vital crafts and skills to the missions of Quebec.

Determined to serve despite his earlier handicap, René Goupil volunteered and was accepted as a donné. He arrived at Quebec in 1640 and worked at the mission of St. Joseph de Sillery. When not involved in the treatment of the sick and wounded, he performed menial duties. His skills and dedication to religious and medical service were keenly appreciated by the priests.? While no case records remain, at least one therapy employed by the French was learned 
from the Hurons. Scurvy, a scourge of Champlain's first wintering party, could be arrested by a tea concocted from the bark and needles of the white spruce. ${ }^{8}$

The only potent analgesic René could have employed was opium, for his life antedated the discovery of general anaesthesia by two centuries. However, this period of global exploration brought an awareness of potent and often poisonous botanical extracts which have since influenced anaesthesiology. Calabar beans from West Africa yielded physostigmine. Spanish and Portuguese adventurers exploring South America described both the virtues of quinine and lethal nature of curare. English travellers returning from the North American colonies brought tobacco. British settlers in Virginia saw their cattle suffer atropine intoxication after ingesting jimson or "Jamestown" weed.

These agents could not be appreciated adequately without the laboratory studies of later centuries, but medicine was already rising above mediaevalism. Vesalius published his anatomical text in 1543, about the time that Valerius Cordus discovered ether. Four decades later Paré began a revolution in the management of battlefield trauma. Twelve years before Goupil arrived in Quebec, Harvey described the function of the heart and circulation of the blood in "de Motu Cordis".

Rough and demanding as life was in Quebec, much of the attention of the Jesuits was focused on the west where Brébeuf and other missionaries visited and travelled among the distant Huron and Algonquin villages. In 1639 they had begun the construction of the first western missions between Lake Simcoe and Lake Huron with Sainte Marie as the administrative centre.

After learning of an urgent need for a surgeon at Sainte Marie, Goupil volunteered to accompany Father Isaac Jogues and a fellow donné, Guillaume Couture, on the arduous and hazardous canoe journey to Sainte Marie.

These three, accompanied by 40 Hurons, paddled up the St. Lawrence River. A band of Mohawks, enemies of the French since the time of Champlain, ambushed and overpowered the travellers one day's journey beyond Trois Rivières on August 2, 1642.

From the moment of their capture Jogues, Goupil, Couture and the Huron survivors experienced cruelty, torture and profound humiliations. The journey south along Lake Champlain and Lake George to the Mohawks' village of Ossernenon (now Auriesville, New York) was a nearly continuous pageant of pain; running the gauntlet, repeated suspension from a rude scaffolding, nights and days staked to the ground while enduring clubbings and brandings, extraction of finger nails and digital amputations. Soon after the arrival in Ossernenon, Couture was carried away to another village.

Despite these horrors Goupil attended both captives and captors. He "... dressed the wounds of other persons, of enemies who had received some blow ... And he did it all with as much charity as if he had done it to persons who were his best friends." "He also refused opportunities to escape in order to stay with Isaac Jogues. For these acts of piety and service Father Jogues accepted his vows as a Jesuit brother. A few days later René Goupil was killed after blessing a small child.

Despite great peril Father Isaac Jogues survived and eventually escaped the Mohawks. Shielded at great risk by Dutch traders, he found passage to Europe and related the martyrdom of Goupil to his superiors. ' Jogues' absolute dedication to evangelism led him to return to Quebec. In 1645 he experienced a joyful reunion with Guillaume Couture who was released from captivity. Couture later spent years exploring the wilderness between the St. Lawrence River and James Bay in search of trade routes. In 1646, however, Jogues and Jean de la Lande, another donne, shared the death of martyrs in the same village where Goupil had died.

Before the Jesuits abandoned Sainte Marie in 1649 , five other priests had come to martyrdom. Canonization was conferred on the eight slain missionaries in 1930. The group were collectively established as Patron Saints of Canada on October $16,1940.10$

\section{The Past Preserved}

The dramatic history of the devotion and heroism of the Jesuit Mission period has been brilliantly captured in E.J. Pratt's epic poem "Brébeuf and His Brethren."1" The powerful imagery of Pratt's work describes the Jesuits" experiences and evangelistic motivation. Travellers may also return to this period of history by visiting the museum in the Sillery House near Quebec City. Goupil worked in this building which is recognized as the oldest surviving structure in Canada. Near Midland, Ontario, the University of Western Ontario's Department of Anthropology under Dr. Wilfred Jury has performed exceptionally fine excavations of the site 
of Sainte Marie des Hurons. With this information the Government of Ontario has prepared a superb recreation of the mission. The buildings, pallisades, furnishings, relics and a film reenactment of mission life are compellingly presented. The contrasts between the European and Indian cultures of that time are reinforced by a visit to an adjacent authentic reconstruction of a Huron Village.

Two religious centres also commemorate the Jesuit mission. A Canadian memorial is the Martyrs' Shrine which overlooks reconstructed Sainte Marie at Midland, Ontario. The National Shrine of the North American Martyrs at Auriesville, New York lies near the New York State Thruway west of Schenectady. As this is the site of Rene's death, greater attention is given St. René at Auriesville, but both shrines maintain their dedication to the Christian convictions that motivated the martyrs.

\section{The Patron Saint of Anaesthetists}

The association between St. René and anaesthetists arose through the activities of two American nurse anaesthetists, Mrs. Leona Higgins and Sister Odila Diedrich. They sought a Patron Saint for anaesthetists and gained the support of Father Francis Przybylski, the hospital chaplain at Wausau, Wisconsin. Father Przybylski researched the lives of the few physician saints of ancient history but was not satisfied that any of these choices would be appropriate.* Some time later a chance encounter with a Brother René led him to an appreciation of a little-known North American martyr, René Goupil, the last physician to be canonized. Convinced that this was the right selection, Father Przybylski petitioned his Bishop and eventually patronage was authorized on September 25, 1951.

St. René Goupil is venerated by Roman Catholic anaesthetists and patients. All Canadians share respect for an heroic and dedicated pioneer of early Canada, who, in the words of his contemporary and companion, " "... dedicated his life, his heart, and his hands to the service of the poor ..."12

* Saint Luke, Pantaleon, Cosmas and Damian were physicians near the time of Christ and are the Patron Saints of all physicians and surgeons. To the writer's knowledge, the only other group of medical specialists to have a Patron Saint are Radiologists who are represented by St. Michael the archangel.

\section{ACKNOWLEDGEMENTS}

I wish to express my deep appreciation to Mrs. Ann Schaldach, CRNA, and Ms. Loretta Schwider, CRNA, who favoured me with a medal of St. René. The identity of this unknown figure remained an enigma as my attempts to identify him from local sources were unsuccessful. Through the kind assistance of Rev. Edward Surges, S.T.L., Rector of St. René Church, Chicago, Illinois, Rev. J. Winston Rye, S.J., Director of the Martyrs' Shrine, Midland, Ontario, Rev. Thomas J. Egan, S.J., Director, National Shrine of North American Martyrs', Auriesville, New York, Sister Odila Diedrich, S.D.S., Milwaukec, Wisconsin, and Rev. Francis Przybylski, Rector of St. Francis Xavier Church, Knowlton, Wisconsin, the mysteries of St. René's history and relationship with anaesthesia were resolved.

\section{REFERENCES}

1. MacDermott, H.E. Notes on Canadian medical history. British Medical Journal I: 925-930 (1955).

2. Heacerty, J.J. Four Centuries of Medical History in Canada. Vol. I. Toronto: Macmillan Co. of Canada. p. 225 (1928).

3. Kenton, E., Ed. The Jesuit Relations and Allied Documents. New York: Vanguard Press. pp. 189-202 (1954)

4. Thurston, H. \& Atrwater, D. "Butler's" Lives of the Saints. London: Burns Oates. p. 649 (1956).

5. Brown, G.W. \& Trude1, M., Eds. Dictionary of Canadian Biography. Vol. I. Toronto: University of Toronto Press. pp. 343-344 (1966).

6. Ibid.

7. MacDougall. J.A., Ed. Martyrs of New France. Midland, Ontario: Martyrs' Shrine Publication. p. 1 (1972).

8. Costain. T.B. The White and Gold - The French Regime in Canada. Garden City, New York: Doubleday \& Co. p. 36 (1954).

9. Kenton, E. The Jesuit Relations and Allied Documents. New York: Vanguard Press. p. 205 (1954).

10. MacDougall, J.A., Ed. Martyrs of New France. Midland, Ontario: Martyrs' Shrine Publication. p. viii (1972).

11. Pratt, E.J. Collected Poems of E.J. Pratt. Toronto: Macmillan. (1968).

12. MacDougall, J.A., Ed. Martyrs of New France. Midland, Ontario: Martyrs' Shrine Publication. p. 1 (1972). 


\section{RÉSUMÉ}

René Goupil, patron des anesthésistes et aussi un des patrons du Canada, est né à Angers, France en 1608 et étudia la chirurgie. Il se joint aux Jésuites comme donné ou travailleur bénévole en 1640 et servit dans la petite colonie de Québec comme un des premiers travailleurs de la santé du Canada. Après s'être attiré des louanges bien mérités par sa compétence, il se porta volontaire à Sainte-Marie chez les Hurons qui était à ce moment une mission fort éloignée. A la suite d'une ambuscade René qui faisait partie d'un groupe voyageant en canot fut fait prisonnier et dut subir de cruelles tortures pendant huit semaines avant sa mort qui survint le 29 septembre 1642. René Goupil fut le premier des huits martyrs d'Amérique du Nord dont les mérites furent reconnus par la canonisation en 1930. Saint René devint le patron des anesthésistes en 1951. 